\title{
Understanding student engagement with social entrepreneurship: a case study of the University of Northampton
}

\author{
Terry Tudor, University of Northampton \\ Cleber Dutra, Universidade de Fortaleza (UNIFOR)
}

\begin{abstract}
The development of skills for social enterprise is a key learning outcome in UK higher education. Using semi-structured interviews and questionnaires with students at the University of Northampton, this study aimed to examine the key factors that impacted upon student engagement with social entrepreneurship. The study showed that while levels of engagement were generally low, there were significant opportunities to improve these levels. A range of psycho-sociological factors (e.g. behavioural intentions, fears of debt, and awareness), as well as socio-demographic factors (e.g. gender), were found to have impacted upon student engagement with the concepts. Recommendations for increasing engagement including improving awareness, being mindful of terminology used, access to funding, and the need for greater cross-faculty working are suggested. While this is only a limited case study, the implications of the findings for wider UK HEIs such as provision of adequate funding and support, and the need to address key concerns such as student perceptions of links between grants and loans to debt, and limited awareness of social entrepreneurship, are also discussed.
\end{abstract}

Keywords: Social entrepreneurship; University of Northampton; HEIs; social innovation; social enterprise

\section{Introduction}

The UK Government aims to inspire a more enterprising approach amongst students and to promote increased innovation (BIS, 2011; HEFCE, 2011). Indeed, within the past five years, entrepreneurship in the UK higher education (HE) sector has been heavily driven by government policy on fiscal and economic measures, education and regional development (Rae et al., 2012). It is one of four strategic goals for universities, with significant government funding via the Higher Education Innovation Fund (HEIF) (Smith \& Beasley, 2011). According to QAA (2012), entrepreneurship education is concerned with developing and applying an enterprising mind-set and skills in establishing a new venture, developing and growing an existing business, or designing an entrepreneurial organisation. Around 93\% of UK higher education institutions (HEIs) support student enterprise and graduate entrepreneurship. However, while this is the case and most universities in the UK work closely with businesses, encouraging students to become involved in social entrepreneurship is still relatively new (Grabham, 2012).

Using the University of Northampton (UoN) as the case study HEI, the overarching aim of this study was to examine engagement with the concepts of social entrepreneurship amongst students in the UK HE sector. In the context of this study, engagement should be taken to be with 
teaching and learning activities, as well as wider university initiatives such as accessing funding and support to establish enterprises.

\section{The concepts of social entrepreneurship}

The concept of social entrepreneurship means different things to different people (Zahra et al., 2008). For example, various authors (e.g. Mair \& Marti, 2006) note that social entrepreneurship aims to realise social value, while earning an income. Others (e.g. Weerawardena \& Mort, 2006; Peredo \& Maclean, 2006), go beyond this view, to argue that it is a multi-dimensional construct framed around developing new and novel social initiatives, through innovative processes, with the overarching aim of creating social-value opportunities. Within universities it can take a number of formats, including student placements, university staff procuring or providing services to social enterprises, or students setting up their own businesses. Social entrepreneurship activities arise in response to a number of socio-economic factors. These include corporate social responsibility, efforts to address global wealth disparity, shared responsibility and technological innovation, institutional and state failures (Zahra et al., 2008).

Social entrepreneurship is moving towards being a discipline within its own right, and is a growing field (Iacobucci \& Micozzi, 2012). It is based on social constructivist theories of learning and knowledge (e.g. Bandura's (1977) concepts of self-efficacy) (Gibb, 2011). Social constructivism emphasises the importance of culture and the social context for cognitive development (Vygotsky, 1978).

\section{Student engagement with social entrepreneurial concepts}

The development of social entrepreneurship initiatives within the HE sector is dependent on role models and the experiences of those developing the curricula (i.e. role theory) (Walter \& Dohse, 2009). Thus at the institutional level, it is crucial that programmes create the environment to inspire learning for entrepreneurship (Hannon, 2005; Rae, 2007; Huq \& Gilbert, 2013). The style of teaching should not only serve to motivate and engage students, but should also employ a constructivist approach to encourage them to actively construct their own knowledge (Weimer, 2002; Biggs, 2003). Thus, teaching and learning about entrepreneurship should involve experiential learning encompassing self-management, self-direction, reflection and autonomy, and be work based (Kolb, 1984; Sobiechowska \& Maisch, 2007; Huq \& Gilbert, 2013). Notions of responsibility, ethics and environmentalism should also be incorporated into the curricula (Pittaway \& Cope, 2005; Hannon, 2005; Rae, 2010).

At the individual level a number of factors are important. For example, the opinions of significant others (e.g. family and friends), can shape entrepreneurial intentions (i.e. stakeholder theory) (Kolvereid, 1996; Welsh \& Krueger, 2012). Indeed, subjective norms, behavioural intentions and attitudes play a significant role in the likelihood of students establishing social enterprises (Krueger et al., 2000; Liñán \& Chen, 2009; Engle et al., 2010; Marques et al., 2012) (Fig. 1). 


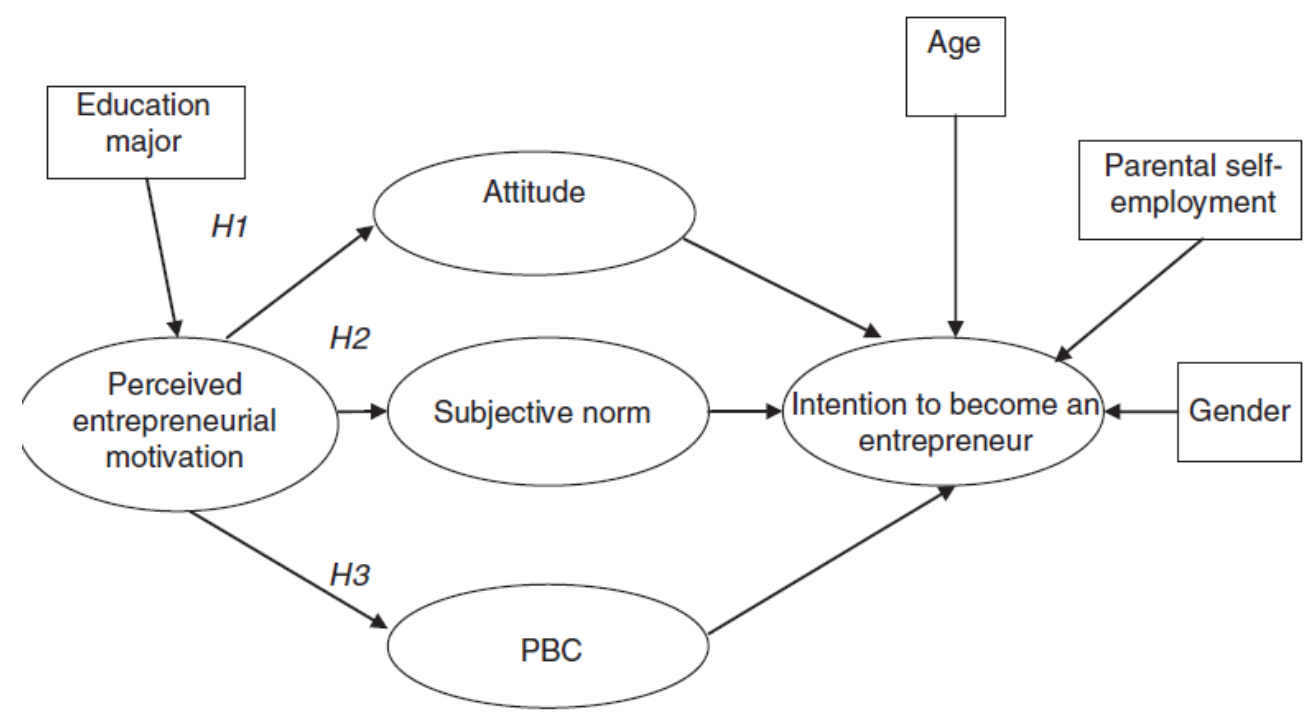

Figure 1: Constructs impacting upon entrepreneurship intentions (from Solesvik, 2013, p.257)

Perceptions of the general socio-cultural environment are also important (Stephan \& Uhlaner, 2010). Beliefs about issues such as risks and potential success also play a role (Lent et al., 2000; Bullvag et al., 2010). Possessing greater entrepreneurial motivation (i.e. beliefs and desires about organising and managing operations and individuals), as well as risk taking, also increase the desire to establish social enterprises (Hessels et al., 2008; Solesvik, 2013). Similarly, Robertson and Collins (2003) found that motivation, access to finance, generating a good idea, and skills were major contributing factors to establishing an enterprise. The impact of socio-demographic factors on engagement with social entrepreneurship is strongly debated. For example, Marques $e t$ al. (2012) found a relationship with factors such as age, gender, education and family background. Some report that women are less likely to start high profit enterprises (Reynolds et $a l ., 2004$ ), in part due to differences in value systems regarding profit making (Bird \& Brush, 2002; Morris et al., 2006). Female students tend to start businesses to gain independence (Carter \& Cannon, 1991), and for social good (Hisrish \& Brush, 1987), while males do so for monetary objectives and profit (DeMartino \& Barbato, 2002). However, others have found that there was no difference in levels of engagement with social entrepreneurship between male and female students (Minniti et al., 2005; Jones et al., 2008). Other key factors influencing engagement have been found to include passion, enthusiasm, initiative and persistence (Davey et al., 2011; Rae \& Woodier, 2006).

\section{Universities and social entrepreneurship}

Facilitating future exmployment and skills development are central roles of universities (Evans, 2008). Indeed Jones et al. (2011) argues that entrepreneurship should be grounded in student learning. Similarly Blenker et al. (2011) stated that educational approaches should facilitate entrepreneurship becoming an everyday practice. According to Universities UK (2012) the key factor is the development of an enterprise culture - one that encourages innovation and creativity at all levels. While sources vary, funding for entrpreneurship primarily comes from governments, 
own institutions, the European Union and sponsorship. Other key sources include private funding, the Higher Education Funding Council for England (HEFCE), and the social enterprise organisation UnLtd (UnLtd, 2013). Student grants and loans are also available (e.g. StartupBritain).

Recent cuts in government funding have had significant knock impact on the viability of social entrepreneurship initiatives (Rae et al., 2012). This fall in funding, coupled with the increasing need for UK HEIs to differentiate themselves from the competition, and the 'real world' opportunities entrepreneurship provides, means it is becoming a more significant focus for many institutions.

\section{The University of Northampton and social entrepreneurship}

In 2010, the University of Northampton (UoN) set itself the strategic goal of becoming Britain's leading university for social enterprise by 2015 (UoN, 2010). In 2013, Ashoka U, the world's leading network of social entrepreneurs, awarded The UoN the international accolade of 'Changemaker Campus', in recognition of its commitment to social enterprise. It is the first university in the UK and Europe to achieve this honour, and one of only 24 in the world. Its social enterprise work is underpinned by three values (UoN, 2010):

1. Providing a unique student experience of the very highest quality, developing both theoretical and practical competence in social enterprise that prepares the leading social entrepreneurs of the future

2. Encouraging, supporting and developing entrepreneurial skills and enterprising attitudes among students, staff, and the members of the communities it works with

3. Delivering a fairer and more inclusive society

In 2013 there were around 1,500 students actively involved in social entrepreneurship activities, 860 of whom were supported in a business initiative (UoN, 2014). Provision of funding in the form of grants and loans was a key strategy to encourage engagement with entrepreneurship. For example, there was $£ 150,000$ made available for new students and staff students for social entrepreneurship with grants of up to $£ 3,000$ for small scale projects and up to $£ 20,000$ for high potential initiatives.

\section{Methods and analyses}

The study was undertaken in three main, overlapping phases during March - June, 2014.

Phase one entailed a review of published documents on initiatives being undertaken to encourage students in the UK HE sector to become involved in social entrepreneurship. Sources of information included the websites of universities, as well as key agencies such as Social Enterprise UK and UK Universities Hub.

Phase two involved an in-depth analysis of key factors influencing engagement amongst students. This utilised two main tools, namely: (1) interviews with staff involved in promoting social entrepreneurship, including lecturers teaching on entrepreneurship courses, and key staff 
working in employability offices both at universities and support agencies (e.g. UnLtd) and (2) questionnaire surveys of students at UoN. Both the interviews and questionnaires were approved by UoN. Participants for both the interviews and questionnaires had the opportunity to withdraw at any time. Seven letters of invitation were distributed to individuals involved in social entrepreneurship within HEIs, two to staff at UoN and five externally. In addition to the letters of invitation, a participant information sheet and consent form was also sent to each prospective interviewee. A total of three interviews were undertaken. The interviews aimed to understand whether there was a typical/average student that engaged with the concepts of social entrepreneurship, what were the key factors that encouraged student engagement and what strategies could HEIs employ to facilitate and encourage engagement (e.g. the use of loans and grants). During March and April 2014, 60 randomly selected UoN students were surveyed using questionnaires. The questionnaires aimed to understand whether the students were engaged with the concepts of social entrepreneurship. If yes, in what way and what motivated them to become involved, and if no, what key factors would best motivate or incentivise them to do so (e.g. provision of grants and loans). The response rate was $100 \%$ as the questionnaires were hand delivered, without any predetermined bias and collected back on completion.

In Phase three, the recommendations were developed. The interviews were transcribed and key themes (e.g. related for example, to suggestions on how best to encourage engagement) identified. The analysis of the questionnaires employed use of relevant descriptive (e.g. frequencies) and bivariate (i.e. correlation) approaches. The key findings from both the interviews and questionnaires were then triangulated and used to develop recommendations for enhanced engagement.

\section{Results}

\section{Questionnaire surveys}

A Shapiro-Wilk test was undertaken to test the normality of the data. The $p$ value of 0.034 was $<0.05$, thus suggesting that the data were significantly different from normal. Thus nonparametric tests were employed. As illustrated in Table 1, the respondents were primarily young women in the age range of 16-25 years old, from the School of Health (primarily undertaking courses in social work and nursing). At the time of the study, teaching and learning at UoN was delivered through six academic schools. The sample was close to the population as at the time of the study $51 \%$ of students were under 21 years and $64 \%$ were female (UoN, 2014) .

For most, UoN's Blackboard system Northampton Integrated Learning Environment (NILE) and their friends were the main sources of information about what was happening on campus (Fig. 2) 


\begin{tabular}{|c|c|c|c|}
\hline Factor & Categories & Frequency & Frequency (\%) \\
\hline Age range & $16-25$ years & 38 & 66.7 \\
& $26-35$ years & 9 & 15.8 \\
& $36-45$ years & 7 & 12.3 \\
& $46-55$ years & 2 & 3.5 \\
& $>56$ years & 1 & 1.8 \\
\hline Gender & Male & 15 & 26.3 \\
& Female & 41 & 71.9 \\
\hline School & Northampton Business School & 8 & 14.3 \\
\hline & Health & 20 & 35.7 \\
\hline & Arts & 4 & 7 \\
\hline & Education & 5 & 9 \\
\hline & Science and Technology & 13 & 23.2 \\
\hline
\end{tabular}

Table 1: Socio-demographics of the sample

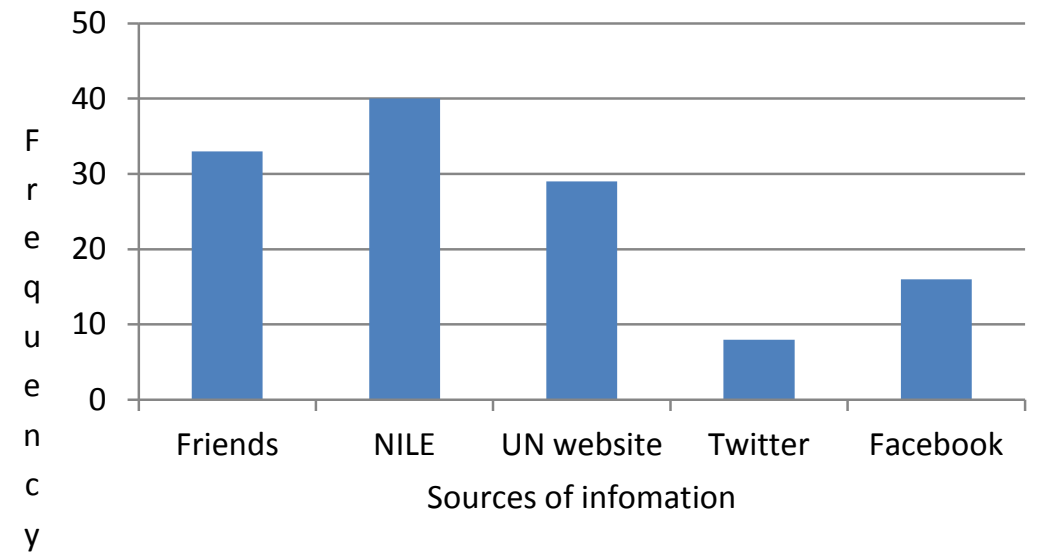

Figure 2: Key sources of information for the respondents

\section{1) Engagement with social entrepreneurship}

Most of the respondents (56\%), were of the view that social entrepreneurship was about 'doing good for the society and making a profit', while 30\% thought it was about 'doing good for the society and the environment'.

Fig. 3 indicates that by the far, the most well know social enterprise initiative was external to the University, Student Hubs (42\%). The next best known were the Dialogue Cafe (21\%) and Social Enterprise UK (19\%). 


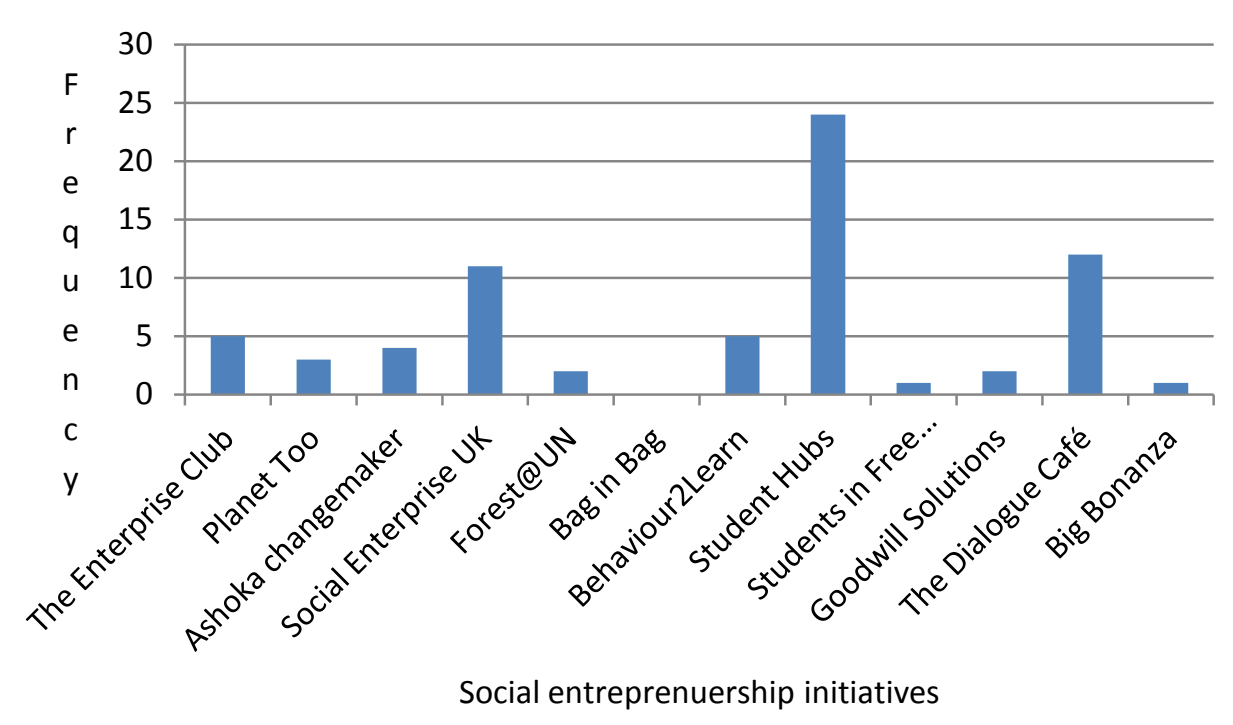

Figure 3: Awareness of selected social entrepreneurship initiatives

Only $12.3 \%$ said they would consider establishing a social enterprise. Indeed, most were not intent on setting up such an entity $(50.9 \%)$, or were neutral about the idea $(36.8 \%)$. There was some correlation between females and starting an enterprise $(r=0.446, \mathrm{p}<0.05)$. There was also a weak correlation between females and the desire to make money from the entities $(r=0.262$, $\mathrm{p}<0.01)$. At the same time, it was female students who most indicated that they did not have enough time $(r=-0.418, \mathrm{p}<0.05)$

\section{2) Reasons for and against engagement}

Fig. 4 illustrates that the main reasons why students indicated they would establish a social enterprise was for social good (17.5\%). Making money was the next key factor (12\%), followed jointly by having a job (10.5\%) and improving the sustainability of the environment $(10.5 \%)$. There was no statistically significant relationship found between course type and a willingness to consider starting an enterprise. 


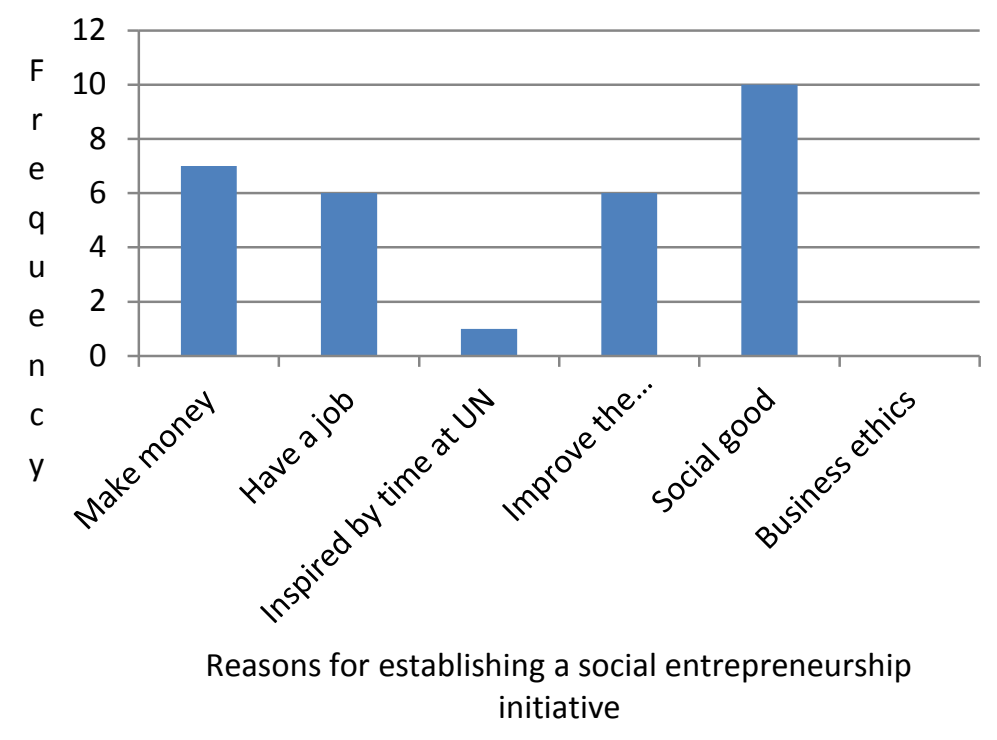

Figure 4: Key suggested reasons for establishing a social entrepreneurship initiative

Alternatively, the perception of not having the time (30\%) was the overriding barrier against establishing a social enterprise. Indeed, there was a significant link between perceptions of having the time and establishing an enterprise $(r=-0.432, \mathrm{p}<0.05)$. Having no interest in the concepts of social entrepreneurship (15.7\%) and wishing to work for an established organisation $(14 \%)$ were the other key factors.

When students were asked whether they would apply for loan or a grant, there was a fairly even split between those that said yes (29.9\%), those that were undecided (35.1\%), and those that said no $(33.3 \%)$. The key underlying barrier identified was that of fear of debt $(29.8 \%)$. Indeed, there was a significant correlation between debt and application for loans or grants $(r=-0.454$, $\mathrm{p}<0.05)$, as well as setting up an enterprise and getting into debt $(r=-0.342, \mathrm{p}<0.05)$. Other factors noted included being unaware of grants and loans $(8.7 \%)$ and a preference to use their own funds (7\%). There was only a weak correlation between awareness of loans and grants and application for one $(r=-0.308, \mathrm{p}<0.01)$. Finally, there was a weak correlation between access to funding and courses undertaken in different schools $(r=0.261, \mathrm{p}<0.01)$.

\section{3) Facilitating engagement}

The overwhelming majority of students $(54.3 \%)$ stated that they would be encouraged to engage more with social entrepreneurship concepts if they had a better knowledge about them and the steps involved in establishing such an enterprise (Fig. 5). Coupled with this need for information, was the requirement for adequate funding $(42 \%)$. 


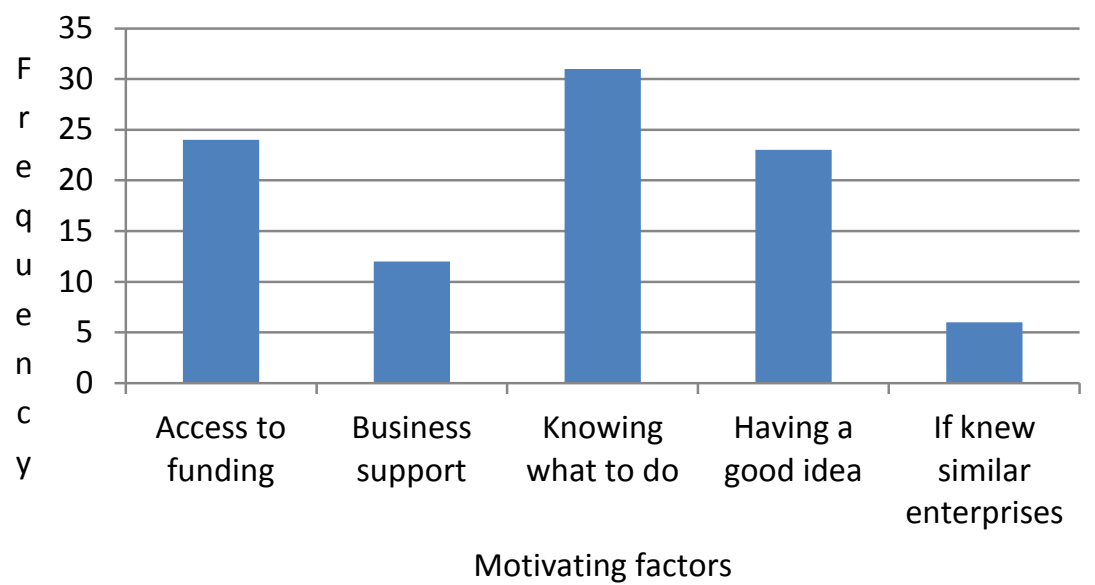

Figure 5: Key motivating factors to encourage engagement

Interestingly, knowledge of the existence of similar social entrepreneurship enterprises was not reported to be a key facilitating factor.

\section{Interviews}

As noted earlier, the interviews aimed to understand whether there was a typical/average student that engaged with the concepts of social entrepreneurship, what were the key factors that encouraged student engagement and what strategies could HEIs employ to facilitate and encourage engagement.

\section{1) Characteristics of students that engaged}

While there was no 'typical' student, the interviewees stated that those students who were more likely to engage most were from vocational courses such as podiatry and social work, as well as from the creative arts (e.g. graphic design). This was because these students were most likely to go on to become self-employed. Students also tended to have some engagement with community activities and therefore were aware of 'social needs', and thus were seeking to establish enterprises that met these needs. For example, Interviewee $\mathrm{C}$ noted:

'In the area of entrepreneurship students, because our profile is ... is quite a lot different to other students at the University. Quite a lot of our students come from backgrounds that haven't necessarily been very traditional, very straight forward. We get a lot of students from ... Northeast London, where they relate immediately to what they've seen growing up in the environments that they've lived in. And they have no difficulty in identifying social problems. Not all of our students come from that background, but a large proportion do and ...often get it, in a way that students who've come from nice comfortable backgrounds don't'.

\section{2) Factors influencing student uptake of social entrepreneurship}


A range of factors that influenced student engagement with the concepts of social entrepreneurship was identified by the interviewees, including terminology, access to funding, and the courses being taken. For example, Interviewee A argued that the terminology employed had an impact and noted that:

'What we've found is that even the word social enterprise can be a barrier, because people don't know what it means, or they have lots of different definitions. We work quite a lot with UnLtd, who are one of the umbrella organisations and they've done a lot of research on barriers to social enterprise, social entrepreneurship. And one of the things they're very keen on is not using the label social enterprise. They like to call it 'doing good stuff'. It's OK to make money, as long as you're doing it in a responsible way'.

Similarly Interviewee $\mathrm{C}$ argued:

'I sit on a lot of committees, a lot of meetings with people from different disciplines and we're all talking different languages - and terminology is part of that problem. I talk about it in terms of a business venture. It's not seen in that way, it's ... and that's $O K$. That's fine. We all have to use our strengths, but we all have to make sure that we're communicating across the University'.

Another key factor identified by the interviewees was that of access to funding. For example, Interviewee B stated that:

'For some things that might be enough, but actually, it's very, very small amounts of money, this is my speculation there are easier ways for students to get hold of $£ 500$, without filling in a whole load of forms and having to be monitored very closely, etc., etc. Especially in these days of crowd funding and whatever. The second thing is that it is absolutely not enough, if you're going to be doing something that involves engineering or technology or creating a product of value'.

\section{3) Facilitating increased engagement}

Interviewee A noted that getting students to engage with the concepts of social entrepreneurship hinged on finding ways to motivate them.

'It's that use of language that you have to change depending on who you're talking to and you have to realise what motivates the students in this School, or what motivates the students in this School. Its different things for different groups of students. And you need to identify what that motivation is'.

A key point mentioned was that of the need for cross university working and partnerships to be forged across departments and disciplines. Indeed, Interviewee $\mathrm{C}$ stated that:

'I think in the same way we as tutors tend to work in silos, the students do. So if you're say a Business School student, you're a Business School student and you never meet anyone else and I think there could be a lot more cross faculty working and many more 
opportunities for linking up with other parts of the University. That's going to make it a stronger University overall, by joining it together and not keeping it separate. Students benefit enormously from working with others in other parts of the University'.

\section{Discussion}

Generally, there appeared to be limited engagement amongst the students sampled with any of the social entrepreneurship initiatives. Given the size of the university, this is contrary to Rae $e t$ al. (2012). The high percentages of those who were 'neutral' about setting up an enterprise, or about applying for a grant or loan suggest that while engagement was low, there are potential opportunities for enhanced engagement, provided that the barriers can be overcome.

Doing social good was a key overriding driver for establishing an initiative. This is in line with the assertions of previous writers about social entrepreneurs having a strong mission, desire and values to realise social value (Thompson et al., 2000; Jiao, 2011). Behavioural intentions were also found to be a strong influencing factor for engagement (Engle et al., 2010). Similar to Rae and Woodier (2006), perceptions about limited time and fear of debt, as well as limitations in awareness were key barriers. Other challenges included the terminology being employed, and the 'small' sums of monies available to set up an enterprise. The impact of perceptions of limitations in time and wishing to work for an established organisation may simply confirm the assertions of others with regard to low engagement when GDP is high (Davey et al., 2011). There was also a statistical link between female students expressing an interest in setting up and enterprise (Minniti et al., 2005; Jones et al., 2008).

\section{Encouraging engagement}

A number of suggestions to facilitate greater engagement were noted. These included the need for enhanced awareness, access to funding, the terminology employed, and facilitating more cross-university working and partnerships.

Limited awareness was noted as a major barrier to enhanced engagement. Thus there is a need for awareness building, using various 'channels' including online learning environments (such as NILE) and peer to peer sharing of information. This awareness building should emphasise the benefits which the students could receive from engagement, as a means of motivation. These promotional activities should also 'walk' students through the steps of establishing an enterprise. A related issue what that of concerns over the time it takes to establish a social enterprise. This could perhaps entail outlining the support that is available, for example, in terms of advice, incubation, technical training, funding and sign posting to external agencies.

There should be the provision of adequate funding and nurturing of 'good' ideas, as has also been suggested by others (e.g. Rae \& Woodier, 2006; Robertson \& Collins, 2003).

The process of accessing support, including grants, should be simple. A range of sums of monies should also be on offer to cater to the needs of various scales of initiatives. As noted by Interviewee $B$, small sums (i.e. less than $£ 1,000$ ), are unable to cover the costs of projects that are science-based and students are more likely to seek elsewhere for such low levels of funding. 
It is crucial that students be reassured that the grants or loans do not equate to 'debt'. Similar to Rae and Woodier (2006), fear of debt was a key constraint. Indeed, the findings suggest that students knew about the loans and grants, but it was the perception of getting into debt that was a major barrier to accessing them. This is significant given the wider economic difficulties being faced by many students. The timing of the allocation of grants and loans is also crucial. Based on the interviews, the first semester appears to be the most appropriate time period, as this is when students are most likely to be engaged in activities within the community. Whilst during the third semester they are focused on final exams and moving back home.

Evidently, the terminology employed is a crucial factor, as social entrepreneurship can mean different things to different people (Zahra et al., 2008). It is important therefore that there should be joined up communication and messages across UoN to avoid confusion.

There is the need to promote greater cross-University working. As argued by Interviewee C, if there are stronger links built across an institution, not only do students benefit, but so too do staff. Different perspectives are brought and ideas shared. In this way, 'silo mentalities' are overcome and intra-disciplinary networks created, thus adding value to existing activities at the university (Gibb, 2011). In this context, an option might be for the creation of a 'standalone' module which could be taken by students across disciplines and schools, to encourage dialogue and links. The module should allow for experiential learning (Sobiechowska \& Maisch, 2007; Huq \& Gilbert, 2013), and perhaps incorporate some aspect of environmentalism (Pittaway \& Cope, 2005; Hannon, 2005).

There is a need for strong networks to be created and sustained not only across interdisciplinary departments, but also across social entrepreneurship funding and support organisations. Stronger networks would play a key role in successful engagement at UoN (Gibb, 2011; UnLtd, 2013; Rae et al., 2012). There could be a central 'hub', with student champions in each school. Indeed, such networks could be more important than providing financial support (Davey et al., 2011). In addition, this would also serve to create social capital by building networks that students could tap into and facilitate the indirect building of competencies and skills.

Finally, there could also be greater opportunities for students to become engaged with entities working in the community, as a means of stimulating awareness and interest (Pittaway \& Hannon, 2008).

\section{Conclusions}

Social entrepreneurship and enterprise are embedded within the strategic vision and objectives of UoN. However, this study has found that there was limited student engagement with the concepts. These limitations were found to relate to a range of psycho-sociological constructs including intentions, fears and awareness. A number of measures for overcoming these barriers have been suggested. Despite the limitations in engagement, the findings suggest there were significant potential opportunities for increased engagement with the concepts amongst students at UoN. 
Enhanced engagement with the concepts of social entrepreneurship has been shown to lead to significant benefits to students, universities and their stakeholders within the community. Indeed, social entrepreneurship is playing an increasing vital role in the UK HE sector and this is likely to increase, within what is an increasingly competitive market place. It is important therefore for HEIs to seek to put in place effective strategies if they are not only to motivate their students to become involved, but also to realise the benefits to be accrued.

\section{Acknowledgements}

The authors would like to acknowledge the assistance of Leo Cleverdon in the collection of the questionnaire data.

\section{References}

Bandura A. (1977) Social learning theory. NY: General Learning Press.

Biggs J. (2003). Teaching for quality learning at university. Second Edition. Buckingham: Open University Press \& McGraw-Hill Education.

Bird B. and Brush, C. (2002) 'A gendered perspective on organizational creation'. Entrepreneurship: Theory and Practice, 26 (3): $41-65$.

BIS (Department for Business, Innovation and Skills) (2011) Students at the heart of the system. London: HMSO

Blenker P., Korsgaard S., Neergaard H. and Throne C. (2011) 'The questions we care about: paradigms and progression in entrepreneurship education'. Industry and Higher Education, 25 (6): 417-428. http://dx.doi.org/10.5367/ihe.2011.0065

Bullvag, E., Kolvereid, L. and Amo B. W. (2010) Global entrepreneurship monitor. Entrepreneurship in Norway 2010. Available from www.gemconsortium.org/docs/download/2273 (accessed 6/12/14)

Carter, S. and Cannon, T. (1991) Women as entrepreneurs: a study offemale business owners. Their motivations, experience and strategies. London: Academic Press.

Davey, T., Plewa C. and Struwig, M. (2011) 'Entrepreneurship perceptions and career intentions of international students'. Education + Training, 53 (5): 335 - 352.

De Martino R., Barbato R. (2002). 'An analysis of the motivational factors of intending entrepreneurship.' Journal of Education for Business, 73 (2): 26 - 36.

Engle, R. I., Dimitriadi, N., Gavidia, H., Schlaegel, C., Delanoe, S., Alvarado, I., He, X., Baume, S. \& Wolff, B. (2010) 'Entrepreneurial intent: a twelve-country evaluation of Ajzen's model of planned behaviour'. International Journal of Entrepreneurial Behaviour and Research, 16 (1): 35-57. http://dx.doi.org/10.1108/13552551011020063 
Evans, C. (2008) 'Developing career management skills within the higher education curricula: a review and evaluation of different approaches.' International Journal of management Education, 6 (3): 45-55.

Gibb, A. (2011) 'Concepts into practice: meeting the challenge of developing entrepreneurship educators' programmes around an innovative paradigm: The case of the International Entrepreneurship Educators' Programme (IEEP)'. International Journal of Entrepreneurship Behaviour and Research, 17 (2): 146-165. http://dx.doi.org/10.1108/13552551111114914

Grabham, A. (2012) Social enterprise day 2012 - universities key to growing social enterprise. Available at: http://blog.universitiesuk.ac.uk/2012/05/15/socent/ (accessed on 7/3/2014).

Hannon, P. (2005) 'Philosophies of entrepreneurship and enterprise education and challenges for higher education in the UK'. International Journal of Entrepreneurship and Innovation, 6 (2): 105-114. http://dx.doi.org/10.5367/0000000053966876

HEFCE (Higher education Funding Council for England) (2011) Opportunities, choice and excellence in higher education. London.

Hessels, J., van Gelderen M. and Thurik, R. (2008). 'Entrepreneurial aspirations, motivations and their drivers'. Small Business Economics, 31 (3): 323-339. http://dx.doi.org/10.1007/s11187$\underline{008-9134-x}$

Hisrish, R. D. and Brush, C. G. (1987) 'Women entrepreneurs: a longitudinal study'. Frontiers in entrepreneurship research. Wellesley, MA: Babson College.

Huq, A. and Gilbert, D. H. (2013) 'Enhancing graduate employability through work-based learning in social entrepreneurship'. Education + Training, 55 (6): 550-572. http://dx.doi.org/10.1108/ET-04-2012-0047

Iacobucci, D. and Micozzi, A. (2012) 'Entrepreneurship education in Italian universities: trend, situation and opportunities’. Education + Training, 54 (8/9): 673-696.

Jiao, H. (2011) 'A conceptual model for social entrepreneurship directed toward social impact on society'. Social Enterprise Journal, 7 (2): 130-149.

http://dx.doi.org/10.1108/17508611111156600

Jones, P., Jones, A., Packman, G. and Miller, C. (2008) 'Student attitudes towards entrepreneurship education in Poland: a positive impact'. Education + Training, 50 (7): 597614. http://dx.doi.org/10.1108/00400910810909054

Jones, P., Miller, C., Jones, A., Packham, G., Pickernell, D. and Zbierowski, P. (2011) 'Attitudes and motivations of Polish students towards entrepreneurial activity'. Education + Training, 53 (5): 416-432. http://dx.doi.org/10.1108/00400911111147721 
Kolb, D. A. (1984) Experiential learning: experience as the source of learning and development. NJ: Prentice Hall, Englewood Cliffs.

Kolvereid, L. (1996) 'Predictions of employment status choice intentions'. Entrepreneurship Theory and Practice, 20 (3): 47-56.

Krueger, N. F., Reilly, M. D. and Carsrud, A. L. (2000) 'Competing models of entrepreneurial intentions'. Journal of Business Venturing. 15 (5/6): 411-432. http://dx.doi.org/10.1016/S0883$\underline{9026(98) 00033-0}$

Kuckertz, A., Wagner, M. (2010) 'The influence of sustainability orientation on entrepreneurship intentions - investigating the role of business experience'. Journal of Business Venturing, 25 (5): 524-539. http://dx.doi.org/10.1016/j.jbusvent.2009.09.001

Lent, R. W., Brown, S. D. and Hackett, G. (2000) 'Contextual supports and barriers to career choice: a social cognitive analysis’. Journal of Counselling Psychology, 47 (1): 36-49. http://dx.doi.org/10.1037/0022-0167.47.1.36

Liñán, F. and Chen, Y. W. (2009) 'Development and cross-cultural application of a specific instrument to measure entrepreneurial intentions'. Entrepreneurship Theory and Practice, 33 (3): 593-617. http://dx.doi.org/10.1111/j.1540-6520.2009.00318.x

Mair, J. \& Marti, I. (2006) 'Social entrepreneurship: a source of explanation, prediction and delight'. Journal of World Business, 41 (1): 36-44. http://dx.doi.org/10.1016/j.jwb.2005.09.002

Marques, C. S., Ferriera, J. J., Gomes, D. N. \& Rodrigues, R. G. (2012) Entrepreneurship education: how psychological, demographic and behavioural factors predict the entrepreneurial intentions. Education + Training, 54 (8/9): 657-672.

Minniti, M., Arenius, P. and Langowitz N. (2005) Global entrepreneurship monitor 2004 report on women and entrepreneurship. Babson College Babson Park, MA.

Morris, M. H., Miyasaki, N. N., Walters, C. E. \& Coombes, S. M. (2006) 'The dilemma of growth: understanding venture size choices of women entrepreneurs'. Journal of Small Business Management, 44 (2): 221-244. http://dx.doi.org/10.1111/j.1540-627X.2006.00165.x

Peredo, A. M. and Mclean, M. (2006) 'Social entrepreneurship: a critical review of the concept'. Journal of World Business, 41 (1): 56-65 http://dx.doi.org/10.1016/j.jwb.2005.10.007

Pittaway, L. and Cope, J. (2005) Entrepreneurship education: a systematic review of the evidence. Paper presented at the ISBE Conference, Blackpool, 1-3 November.

QAA (2012) Enterprise and entrepreneurship education: guidance for UK higher education providers. Gloucester, UK.

Rae, D. (2007) Entrepreneurship: from opportunity to action. London: Palgrave Macmillan. 
Rae, D. (2010) 'Universities and enterprise education: responding to the challenges of the new era'. Journal of Small Business and Entrepreneurship Development, 17 (4): 591-606. http://dx.doi.org/10.1108/14626001011088741

Rae, D. \& Woodier, N. (2006) Graduate career choices and entrepreneurship. Research report 007/2006. National Council for Graduate Entrepreneurship.

Rae, D., Martin, L., Antcliff, V. and Hannon, P. (2012) 'Enterprise and entrepreneurship in English higher education: 2010 and beyond'. Journal of Small Business and Enterprise Development, 19 (3): 380-401. http://dx.doi.org/10.1108/14626001211250090

Reynolds, P. D., Bygrave, W. D. and Autio, E. (2004) Global Entrepreneurship Monitor 2003 Executive report. Babson College \& London Business School.

Robertson, M. and Collins, A. (2003) 'Developing entrepreneurship in West Yorkshire: west Yorkshire universities' partnership and business start-up@Leedsmet'.'Education + Training, 45 (8): 303-307. http://dx.doi.org/10.1108/00400910310495941

Sobiechowska, P. and Maisch, M. (2007) 'Work-based learning and continuing professional development'. Education + Training, 49 (3): 182-192.

http://dx.doi.org/10.1108/00400910710749314

Solesvik, M. Z. (2013) 'Entrepreneurial motivations and intentions: investigating the role of education major'. Education + Training, 55 (3): 253-271.

http://dx.doi.org/10.1108/00400911311309314

Smith, K. and Beasley, M. (2011) 'Graduate entrepreneurs: intentions, barriers and solutions'. Education + Training, 53 (8/9): 722-740.

Stephan, U. and Uhlaner, L. (2010) 'Performance-based vs socially supportive culture: a crossnational study of descriptive norms and entrepreneurship'. Journal of International Business Studies, 4 (8): 1347-1364. http://dx.doi.org/10.1057/jibs.2010.14

Thompson, J., Alvy, G. and Lees, A. (2000) 'Social entrepreneurship - a new look at the people and the potential'. Management Decisions, 38 (5): 328-338.

http://dx.doi.org/10.1108/00251740010340517

UoN (University of Northampton) (2010) Raising the bar. Strategic plan 2010 - 2015. The University of Northampton.

UoN (University of Northampton) (2014) Annual report and consolidated statements for the year ending 31 July 2013. The University of Northampton.

Universities UK (2012) Universities enabling social enterprise - delivering benefits for all. Available at: 
http://www.universitiesuk.ac.uk/highereducation/Pages/UniversitiesEnablingSocialEnterprise.as px\#.VIL1wTGsXTo (accessed 6/12/14).

UnLtd (2013) Evaluation of the higher education support programme. London.

Vygotsky, L. (1978) Mind in society. London: Harvard University Press.

Walter, S. G. and Dohse, D. (2009) The interplay between entrepreneurship education and regional knowledge potential in forming entrepreneurship intentions. Kiel Working Paper, No 1549.

Weerawarden, J. and Mort, G. S. (2006) 'Investigating social entrepreneurship: a multidimensional model.' Journal of World Business, 41 (1): 21-35.

http://dx.doi.org/10.1016/j.jwb.2005.09.001

Weimer, M. (2002) Learner-centred teaching: five key changes to practice. San Francisco, CA: Jossey-Bass.

Welsh, D. H. B. and Krueger, N. (2012) 'The evolution of social entrepreneurship: what have we learned?' Journal of Technology Management in China, 7 (3): 270-290.

http://dx.doi.org/10.1108/17468771311325176

Zahra, S. A., Rawhouser, H. N., Bhawe, N., Neubaum, D. O. and Hayton, J. C. (2008)

'Globalization of social enterprise opportunities'. Strategic Entrepreneurship Journal. 2 (2): 117-131. http://dx.doi.org/10.1002/sej.43

\section{About the author}

Dr Terry Tudor is a Senior Lecturer in the School of Science and Technology, University of Northampton, England.

Email: terry.tudor@northampton.ac.uk

Dr Cleber Dutra is an Associate Professor in the Department of Management, Universidade de Fortaleza (UNIFOR), Fortaleza, Ceará, Brazil

Email: cleber.dutra@unifor.br 